\title{
Reflections on developing indicators for campus sustainability from a fragility perspective
}

\author{
Authors: Monika Paradowska, Santa Bukauskaitè, Gytys Rimkus, Alexander Heller, \\ Akim Sharapov, Nika Magradze, Joost Platje
}

\begin{abstract}
Aim: Provide a summary of the discussion at the workshop on "Methodology for assessing the campus sustainability from the perspective of multi-level antifragility" held on Friday 13 May at the WSB University in Wrocław, as well as reflection notes each of the participant wrote after the workshop. The paper shows the outcome of the process of interaction and reflections of the authors regarding the methodology of assessing campus sustainability using a fragility approach.

Design / Research methods: This article contains feedback based on the experience and ideas from students from Georgia, Germany, Kazakhstan and Lithuania. Discussion took place during the workshop in focus groups. Afterwards, a discussion took place among all participating students and lecturers. After the workshop, the authors wrote individual feedback notes. These are summarized in this paper.

Conclusions / findings: Although there are promising element that can be developed into a framework of assessing campus sustainability from a fragility perspective, many challenges appear. In particular challenges in defining unambiguous indicators as well as finding proper sources of information were identified.
\end{abstract}

Originality / value of the article: The article provides critical feedback on an innovative approach towards research on campus sustainability.

Keywords: campus sustainability, sustainability management, fragility, antiHistory: received 2016-11-25, corrected 2016-11-27, accepted fragility, methodology

JEL: Q01, B40, I23 2016-11-27

Alexander Heller

nikulina1234@gmail.com
Joost Platje

WSB University in Wrocław johannes.platje@wsb.wroclaw.pl 


\section{Introduction}

The aim of this paper is to summarize arguments discussed during the focus group discussion at the international workshop "Methodology for assessing the campus sustainability from the perspective of multi-level antifragility" held at the WSB University in Wrocław (Poland) on Friday 13 May 2016. The discussion was assessed after the workshop by individual participants in reflection papers. The outline of the workshop and questionnaire discussed can be found in the first article of this special issue. This paper does not have the pretention to be a scientific treatise on the issues discussed at the workshop. The paper shows the outcome of the process of interaction and reflections of the authors regarding methodological issues.

\section{Methodological issues}

The focus group consisted of students from different countries with different backgrounds, mainly economics and engineering. Also some lecturers took part in the focus group discussion, while afterwards an open discussion took place between students and university teaching and research staff. In this discussion it became clear that the different backgrounds influence the assessment of the indicators of organizational viability. This was a strong point of the open discussion it offered everyone the opportunity to participate. Not only the indicators of campus sustainability could be assessed and criticized, but also new ideas came up. Furthermore, it provided an opportunity to get acquainted with different points of view originating from different backgrounds, which can have a good learning effect.

One challenge identified is that different stakeholders have different priorities. It is not surprising that quality of teaching was important for students, while scientific research and access to research funds was relevant for the lecturers. As a consequence, it may be that, for example, students underestimate the importance of good science for university viability. On the other hand, lecturers may underestimate the importance of social life (student organizations, clubs, events, etc.) in the choice of the university as the place of study.

Another issue is difficulties with finding a representative sample within a group of stakeholders. For example, as a participant wrote: "maybe our program is perfect, with a lot of approaches and good lectures. But in another faculty it might be vice versa, because their lecturers are all the time late, without passion on their subject. This means that four people from the same study program filling out the same questionnaire, might end up with different answers, because they experienced other things." Thus, in the assessment of indicators there exists the problem of subjectivity and opinions developed based on cases, stories, examples, etc. Probably, all students from all faculties should fill out the questionnaire on campus sustainability in order to get a representative picture. However, a problem to be dealt with is the experience of students based on the number of years they study.

In the discussion about indicators, the participants obtained the following task. "Please assess whether you consider the following to be relevant or irrelevant for the identification of fragilities. Please assess the indicators you think are relevant on the seriousness and likeliness (probability) of potential threats related to the indicators for the organizational viability of the university as well as the sustainability of the external environment. Please assess seriousness and likeliness with $\mathrm{H}$ (high) and L (Low)." (Quote of the questionnaire from the conference. 
The indicators can be found in the Annex of the first article of this special issue.)

A challenge in the discussion was that many indicators had different meanings for different participants. In other words, they were ambiguous, open to a wide range of interpretations. This made it difficult to assess the likeliness of an event happening, as well as the impact on organizational viability and external sustainability. This may have been a purpose or the workshop organizers, as it stimulated a lively discussion into the deeper meaning, while showing that a phenomenon as such to a certain point may not be problematic at all.

Let's take the example of strong interest groups. A strong and motivated group of students and/or teachers can force through changes supporting sustainable development and create an interesting study programme. But an interest group can also defend its own interests in a way that hampers change and the introduction of new ideas for a more sustainable university and society. Also important is whether there is a struggle between interest groups. For this reason, this indicator should be accompanied, for example, by an indicator regarding the type of interest group (Freeman 1984).

An example of an ambiguous indicator is "making mistakes." This indicator probably refers to a negative event. However, questions in the first part of the questionnaire concern "mistakes and learning-by-doing." Thus, as such, making mistakes is not bad as long as there are learning effects. Small mistakes, such as wrong information in a student's ID, rather causes inconveniences for the individual student. A calculation mistake in the university budget can lead to major problems. It follows from this, that a distinction can be made between "positive mistakes" (creating learning effects) and "negative mistakes" (threatening the viability of the university). Though, a fundamental problem remains that, depending on the situation, the same mistake can have different impacts. Like with a hammer - it can be used for the construction of a table, but also to smash someone's head. This implies that indicators of mistakes should be analysed in the context of other indicators, like critical discussion or hiding the truth, as they show whether mistakes are discussed, creating opportunities for learning effects.

Another issue is that many indicators are connected to the functioning of the organization as such, and not with, for example, environmental elements of sustainable development. An example is a question from the first part of the questionnaire: "The things at my university are so bad it can't get any worse." It seems that maybe too much emphasis is put on the organization's viability, and indirectly to its capacity to deal with issues of sustainable development and/or to fragilize the external environment. However, the capacity to deal with challenges does not necessarily have to lead to a positive influence on sustainable development. A university which has a lot of problems (such as underfunding, administrative chaos, lack of students) will vanish in the long run. When improving the organizational viability, these issues are likely to receive priority.

\section{Concluding remarks}

The main focus of the discussion and reflection notes was on methodological issues. The most important points were presented in this paper. The remarks and ideas discussed are based on personal reflections on the explorative research method which was the main topic of the workshop. As different individuals understand statements differently, evaluation of universities and indicators may significantly differ 
within small groups, even when participants are from the same university. As a consequence, the outcome of such a workshop should be interpreted with extreme care, as when a focus group decides an indicator is unimportant, it is likely that this may only reflect an idea that needs deeper elaboration.

Furthermore, students may be a poor source of information regarding many indicators, as most of them just may not possess enough information or knowledge. This effect may be strengthened by the limited amount of time available for discussion. However, as students are an important stakeholder regarding university viability (without students a university would not exist), they can be a useful source of information regarding fragilities that may lead to a reduced amount of students enrolling at the university.

As was discussed, indicators should be unambiguous in order to make universities comparable. The ambiguity of some indicators may have been useful for the aim of the explorative workshop, as this stimulated discussion. It led the focus group to the conclusion that there may be a threshold up to where mistakes, just to mention an indicator, are not harmful. Also, there may be "positive mistakes" and "negative mistakes." In the first case, these mistakes provide information and knowledge from which people can learn. The second mistakes rather lead to fragilities threatening organizational viability. When writing this paper, attention was drawn to the fact that similar thought can be found in Nassim Taleb's (2012) work.

However, as students may rather focus on the quality of education and scientists on research funds and conditions for doing research, a viable university does not necessarily focus on sustainability issues. This aspect is included in the questions about the university's impact on the sustainability of the external environment. This issue needs serious study as in the current approach it can only be assessed whether a university harms the external environment. Although it may have been the intention of the theoretical ideas behind the workshop, that is can be identified to what extent the university causes damage, also some positive action or impact should be included as this can be, for example, more easily included in teaching practice.

\title{
Bibliography
}

Freeman E.R. (1984), Strategic Management: a stakeholder approach, Pitman, Boston.
Taleb N.M. (2012), Antifragile - things that gain from disorder, Penguin Books, London.

\section{Uwagi na temat opracowania wskaźników zrównoważonego rozwoju kampusu z perspektywy kruchości}

\begin{abstract}
Abstrakt
Cel: Tekst streszcza dyskusję przeprowadzoną podczas warsztatów na temat "Metodologia oceny zrównoważonego rozwoju kampusu z perspektywy antykruchości wielopoziomowej" zorganizowanych przez Wyższą Szkołę Bankową we Wrocławiu w piątek, 13 maja 2016 r. i zawiera informacje zwrotne uczest-
\end{abstract}


ników tej dyskusji, które pozostawili w formie notatek. Prezentuje ponadto wynik procesu interakcji i refleksji autorów na temat metodologii i oceny zrównoważonego rozwoju kampusu z wykorzystaniem perspektywy kruchości.

Metoda badawcza: Artykuł zawiera informacje zwrotną opartą na doświadczeniu i pomysłach badawczych studentów z Gruzji, Niemiec, Kazachstanu i Litwy. Dyskusja najpierw przebiegała w grupach fokusowych, a następnie z udziałem wszystkich uczestników i wykładowców. Po zakończeniu warsztatów uczestnicy sporządzili notatki zawierające informacje zwrotne, których streszczenia zostały omówione $w$ artykule.

Wnioski : Mimo wielu obiecujących pomysłów, które mogą doprowadzić do opracowania ramy badawczej zrównoważonego rozwoju kampusu z perspektywy kruchości, pojawia się również wiele wyzwań. Należy do nich głównie zdefiniowanie jednoznacznych wskaźników i poszukiwanie właściwych źródeł informacji.

Oryginalność / wartość artykułu, wkład w rozwoju nauki: Artykuł zawiera krytyczne informacje zwrotne na temat innowacyjnego podejścia badania zrównoważonego rozwoju kampusu.

Słowa kluczowe: zrównoważony rozwój kampusu, zarządzanie zrównoważonego rozwoju, kruchość, antykruchość 
